\title{
Learning from ELLs' Perspectives: Mismatch between ELL and Teacher Perspectives on ELL Learning Experiences
}

\author{
Jenna Min Shim ${ }^{1} \&$ Anna Mikhaylovna Shur ${ }^{2}$ \\ ${ }^{1}$ School of Teacher Education, University of Wyoming, Laramie, Wyoming, United States \\ ${ }^{2}$ School of Teacher Education, Literacy Education Program, University of Wyoming, Laramie, Wyoming, \\ United States \\ Correspondence: Jenna Min Shim, School of Teacher Education, University of Wyoming, Laramie, Wyoming, \\ United States. Tel: 1-307-766-3126 E-mail: jshim@uwyo.edu
}

Anna Mikhaylovna Shur, School of Teacher Education, University of Wyoming, Laramie, Wyoming, United States. E-mail: Ashur@uwyo.edu

Received: October 25, 2017 Accepted: December 1, 2017 Online Published: December 2, 2017

doi: 10.5539/elt.v11n1p21 URL: http://doi.org/10.5539/elt.v11n1p21

\begin{abstract}
Situated within Activity Theory, this study investigates and compares ELLs' perspectives on their own learning and their teachers' perspectives on their own learning experiences. The predilection carried by this study is that there is a significant value in attending to and understanding how ELL students make meaning of their learning circumstances and compare that to teachers' perspectives on their students' learning. This study also assumes that allowing student voice and perspective to be heard in school is a prerequisite for student-centered learning. The authors report that students' perspectives on what they perceive as the limiting factors for their learning are sharply different from those of their teachers. Students' perspectives in this study showed that their perspectives on, and attitudes toward, their learning are very much influenced by what teachers do and do not do.
\end{abstract}

Keywords: English language learners, student voice, activity theory, student learning

\section{Introduction}

\subsection{Introduce the Problem}

Mitra (2004) suggested "student voice opportunities contribute to 'youth development' outcomes in young people" (p. 651). Other research similarly reported that student voice serves as a catalyst for improving teaching and teacher-student relationships (Rudduck, 2007; Rudduck \& Flutter, 2004). Some researchers have found that when student voice is heard and valued in the classrooms, their academic performances have improved (Rudduck \& Flutter, 2004; Mitra, 2004, 2008). Rudduck (2007) argued that "student voice is most successful when it enables students to feel that they are members of a learning community, that they matter, and that they have something valuable to offer (p. 587). Notably, these researchers have also argued that attending to and increasing student voice in schools helped to re-engage alienated students by providing them with a stronger sense of ownership in their schools. Cook-Sather (2009) stated that it is only through taking students' perspectives seriously that educators and students can move forward in increasing our capacity to become "critical thinkers, engaged human beings, and responsible participants in the world" (p. 2). Some researchers go as far as to argue that educational reform cannot succeed without more direct involvement of students in all aspects of their schooling because "teachers are not the producers of learning; in the end it is students who must do the learning" (Levin, 2000, p. 163).

In this regard, the benefits for the student-centered constructivist approach to learning and teaching is not new, and it has been advocated in the field of education for many years. For example, Dewey (1916) and Vygotsky (1978) proposed that learners actively participate in their education and construct new knowledge based on their prior experiences and knowledge, whereby a teacher becomes a facilitator. While some researchers argue that minimal guidance during instruction does not yield satisfactory outcomes (Kirschner, Sweller, \& Clark, 2006), most educators support the idea of the importance of students' active role in their learning. According to student-centered approach, students are placed at the center of the educational matters, whereby their role shifts from a passive receiver to an active co-constructor of knowledge. Not only does the process of student-centered 
learning vary, but can mean different things to different people. Nonetheless, one common aspect that constitutes the definition of student-centered learning is that students are considered active participants who construe and construct their own understandings where their voices are heard and valued (Cook-Sather, 2009; David \& Sumara, 2002; Good \& Brophy, 1994; Mitra, 2004, 2008).

Hence, there is a need to include the student voice in practice of teaching and learning and also in research in a way that allows students to tell their own story rather than simply being recipient of the knowledge being delivered by teachers. Ironically however, while most schools and many researchers struggle to find ways to improve student outcomes, only a few have gone and ask the students about their learning experience. Notwithstanding, the researchers aforementioned who advocate for the importance of increasing student voice and perspectives at their learning needs in schools, students rarely have the opportunity to share their perceptions of potential or existing impediments to learning such as disengagement and lack of motivation (Levin, 2000; MItra, 2008). While educators agree that schools exist for students, their education is usually based on direction from teachers and administrators (Levin, 2000).

The lack of attention to student voice is particularly true for English language learners (ELLs). Research about ELLs' learning generally has focused on teacher and outsider views of success, and the need to understand and ELLs' perspectives of their own learning experiences is undeniable (Best et al., 2015). In this regard, researchers are arguing that there is not enough focus on the student perspective in research on English as a second language (ESL) teaching and learning. There is also growing recognition that teachers and their students have different perceptions about students' learning. For example, Barkhuizen (1998) found that teachers were surprised that their ELLs' perceptions of classroom activities did not match their own. The author made a criticism that ELLs are almost never asked overtly about their learning experiences when in fact that some students' opinions are very similar to those of the literature in the field of second language learning and teaching.

Extending the research that has been conducted about the positive effects of incorporating student voice and the need for ELLs' perspectives to be heard in schools, this study investigates and compares ELLs' perspectives on their own learning and their teachers' perspectives on their own learning experiences. The predilection carried by this study is that there is a significant value in attending to and understanding how ELL students make meaning of their learning circumstances and compare that to teachers' perspectives on their students' learning in order for teachers to discover ELLs' "feelings and beliefs about their language learning experiences and consequently to review and possibly change their teaching process" (Barkhuizen, 1998, p. 86). This study also assumes that allowing student voice and perspective to be heard in school is a prerequisite for student-centered learning (Mitra, 2008).

\subsection{Demographic Reality and Significance of the Study}

Migration affects almost all aspects of contemporary society, whereby we are constantly crisscrossing cultural boundaries both within the country and globally (Papastergiadis, 2000). Because language and culture are inseparable (Vygotsky, 1978), it is not surprising that, in the United States as well as many other countries in the world, ELs are currently the fastest growing population among the school-age group (Pettie, 2011). In fact, the number of ELLs has nearly doubled to about 5.5 million over the past 15 years and, by 2025, nearly one in every four public school students will be an EL in the US (National Clearinghouse for English Language Acquisition [NCELA], 2007; Winke, 2011). Moreover, ELL enrollment is estimated to be increasing at 2.5 times the rate of the general student population (NCELA, 2007). Meanwhile, the widening gap between the demographics of teachers and students from diverse backgrounds, including various linguistic backgrounds, is well documented by research studies (Gay, 2010; Milner, 2003; Sheng, Z., Sheng, S., \& Anderson, 2011). Consequently, teachers and schools are faced with challenges in meeting the needs of ELLs (Bergh et al., 2010; Zumwalt \& Craig, 2005) In many states, ELL dropout rates are significantly higher than those reported for non-ELL students (National Center for Education Statistics [NCES], 2011).

Given the reality, the importance of this study, which aims to explore ELLs' perceptions of their learning experiences and compared that to their teachers' perspectives on the ELLs' learning lies in several areas. First, in recognizing that the rapid growth in the number of linguistically diverse students across the nation and that their level of academic performance is now a concern for all educators, this study will provide valuable information that may assist in addressing these issues. To this end, the researchers will investigate students' own perspectives on their learning which may identity their learning challenges which in turn may help teachers to gain insights that are not available to them otherwise. Next and relatedly, given that ELLs' perspectives on their learning are currently understudied, listening to the experiences of ELLs and identifying possible gaps between the ELLs' and their teachers' perspectives becomes critically important toward not only reforming the classrooms and 
education, but also enabling the ELs to feel empowered which in turn may help achieve fuller academic potential Finally, as this study is conducted in a small town in the Western state, it will appropriately reflect the needs of the ELL population in rural areas in the Western state. According to the National Center for Educational Statistics, the ELL population in the Western states has more than doubled from 1995 to 2005 (NCES, 2011), and that number is continually growing. The next section below discusses the Activity Theory as a framework to understand the importance of attending to and increasing student voice in their own learning experience and needs.

\subsection{Research Question and Hypotheses}

This study is based on the following hypotheses. First, there is a significant value in attending to and understanding how ELL students make meaning of their learning circumstances and compare that to teachers' perspectives on their students' learning. Second, allowing student voice and perspective to be heard in school is a prerequisite for student-centered learning. Based on these two hypotheses, the research questions for this study are: (1) How would you describe your learning experiences in school? (for ELLs), and (2) How would you describe ELLs' learning experiences in school? (for teachers).

\section{Conceptual Framework and Relevant Literature}

Activity theory originates from the dialectical principle of Marxist Philosophy that social being determines the consciousness and the material world should be prioritized over the consciousness (Pines, 1993). Based on this principle, Leont'ev (1981), the co-founder of Activity theory, considered human psyche as a kind of activity. He identified activity as the interaction with the environment. The result of this interaction is the ideal image of the environment that is controlled by the behavior. The main characteristic of the activity is its object that can be either a material item or an ideal object (e.g., thoughts, feelings, and emotions). Along with the process and motive, the object determines activity and an act as the basic unit of analysis of individual and group behavior (Leont'ev, 1975). An individual should be aware of the motive and object of the act. Otherwise, this act won't make any sense to an individual. The act that has an independent motive, becomes activity, because an individual is aware of this motive. The development of the awareness of the motive requires the correlation between this particular activity and broader activity (Ignatyeva, 2012).

As Activity theory became the basis for the concept of learning activity, educators and researchers came up with the idea of the development of situations, in which certain acts should occur, and these acts should have certain characteristics that meet certain requirements (Galperin, 1969). The task of the development of such situations requires the creation of the beneficial conditions, in which these acts can occur. The creation of these conditions can be influenced by such factors as socio-historically conditioned setting, goals, intention, and socio-cultural history of the participants. Therefore, the participant/subject is the agent whose behavior the analyst is focusing in an activity system that is mutually constructed by participants. Within this line of thought, individual learners, who have unique social-cultural histories, are viewed as constructing learning activities in unique ways; therefore, activities differ one from another by each individual's objects and motives (Roebuck, 2000). In this regard, two people, who are given and engaged in the same activities as seen from the outsider's perspective, may actually carry out and learn different things if the motives and goals of these two people differ. The effect then is, these two people in actuality are not engaged in the same activities because the motives and goals underlying their behavior are different (Roebuck, 2000). Donato and McCormick (1994) explain this dynamic in the following way:

An object, in the sense of a goal, is held by the student and motivates his or her activity, giving it a specific direction. To achieve the objective, actions are taken by the student, and these actions are always goal-directed.

Rubtsov (1996) emphasizes the role of collaboration between teachers and students in learning activity. According to this idea, the communication based on mutual understanding, planning, and reflection promotes the development of learning activity. This collaboration is a matter of paramount importance in the ESL classroom, because it also serves as a cultural channel between the student and the teacher, who represents the mainstream culture. The most desired result of this collaboration is students' ability to shape the ultimate outcomes of learning tasks set for them by their teachers, but these learning outcomes should be based on their individual orientations. What can be concluded here is that to understand learning, teachers need to understand how individual students engage with the task by understanding their perspectives of the objectives of tasks and criteria for them to become successful.

Increasing number of ESL researchers have adopted Activity Theory, and Van Lier (2000) contends that how the learner perceives a given activity (tasks given by teachers) are central to understanding the learnings of ELLs. Similarly, Bastturkmen and Lewis (2003) argue that in order to understand learning behavior (their writing in 
this study) and learners' perceptions of their behavior as successful or not, it is necessary to explicate individual and insider understandings by understanding students' own perspectives.

Following the same line of thought, this study is committed to understanding the participating ELLs' perspectives about their learning and the learning tasks set by their teachers. Activity theory is a useful framework for this study that aims to provide ELLs with public outlets for their perspectives in learning which in turn may motivate them in schools. The cause of students' demotivation has often to do with the school's or the teachers' incapacity to understand students' needs, not the students' rejection of the value of education.

\section{Methods}

\subsection{Setting}

This study was conducted in a town located in the south-central portion of a Western US state, home to primarily rural ranching communities and in an English Only state. The town has a population of 9300 residents. Due to many employment opportunities linked to the state penitentiary and coalmines in the town, in the last two decades, the town's predominantly White population has become increasingly diverse, with the greatest increase in the number of Latino residents, but also including individuals from China, Thailand, and the Philippines. Consequently, the ELL population in public schools has more than doubled since the 1990s.

Two elementary schools, one middle school, and one high school provide for the education for the local student population. All four schools implement a pull-out program for ELLs, whereby, during each school day, the ELLs are taught English during one to two hours dedicated to other main/content-area subjects taught to the rest of their class. Currently, $26.6 \%$ of the total student population is Hispanic, and Asians and Native Americans account for $4.1 \%$ of the student enrollment. Moreover, $11.8 \%$ of the total student population qualifies for the English as a Second Language (ESL) services, and over $15 \%$ of the total student population lives in a home where one or both parents do not speak English as their first language.

\subsection{Student Participants}

Two middle school students and two high school students volunteered to participate in this study, all of whom lived in the US for 3 to 4 years. All participants self-identified Chihuahua, Mexico as their place of origin. In order to protect their privacy and ensure confidentiality, in this work and any subsequent reports, all participants will be referred to by their pseudonyms. Their demographic data is presented below. All names are pseudonyms.

Table 1. Demographic data of the student participants

\begin{tabular}{lllll}
\hline Name & Grade & First Language & Years in the U.S. & Home Country \\
\hline Juan & 7 & Spanish & 4 & Chihuahua, Mexico \\
Carla & 7 & Spanish & 3 & Chihuahua, Mexico \\
Carlos & 9 & Spanish & 3 & Chihuahua, Mexico \\
David & 9 & Spanish & 3 & Chihuahua, Mexico \\
\hline
\end{tabular}

\subsection{Teacher Participants}

The teachers who participated in this study are two female elementary school ESL teachers, one female middle school teacher, and a male and a female high school ESL teacher. Their teaching experiences range from 3 to 8 years, and they all agreed to participate in this study. All participating teachers are White Americans, aged 24 to 45, and are all monolingual speakers of English. All teacher participants have an ESL endorsement attached to their teaching certificates, and each participant had her/his own ESL classroom when the study was conducted. The following is a table of the participants' demographic data. All names are pseudonyms.

Table 2. Demographic data of the teacher participants

\begin{tabular}{llllll}
\hline Name & School & Race & Language(s) & Yrs. Of ESL Teaching & Age \\
\hline Linda & Elementary & White & English only & 6 & 38 \\
Mary & Elementary & White & English only & 3 & 24 \\
Nancy & Middle & White & English only & 8 & 45 \\
\hline
\end{tabular}




\begin{tabular}{|c|c|c|c|c|c|}
\hline Karen & Middle & White & English only & 6 & 35 \\
\hline Dave & High & White & English only & 4 & 32 \\
\hline
\end{tabular}

3.4 Data Sources

\section{Students}

The data for this study was collected through twelve semi-structured individual interviews with students, even though not all are directly quoted in this study. Drawing on the criteria established by Bamberg (2004) and guided by the conceptual framework of this study which highlights the role of learner as active in their learning, we focused on listening to the participants' stories that index in a compelling way that revealed their views on their learning in school setting. Each student participated in three interviews with the researcher (the first author), with each interview lasting about 45 to 60 minutes. All interviews were conducted between September 2012 and February 2013, and aimed to elicit students' own stories that would answer the questions guiding this study: How would you describe your learning experiences in school? What do you experience as the factors that enhance and/or limit your learning experiences in school? All interviews were conducted in English, and detailed notes were taken by the first author. All interviews were also tape-recorded, and were subsequently transcribed by the first author. The notes were compared with the transcribed data and with the second author to check for consistency and/or contradictions.

\section{Teachers}

This study draws on 10 semi-structured individual interviews with teachers, even though not all are directly quoted in this study. Each teacher participated in two interviews with the researcher, each lasting 1-1.5 hours. All interviews were conducted between September 2012 and February 2013. Interviews aimed at eliciting responses that would answer the main question: What are your beliefs about ELLs' learning experiences in school? What do you perceive to be the factors that enhance and/or limit ELLs' learning experiences in school? Detailed notes were taken by the researcher. All interviews were also tape-recorded, which were then transcribed by the researcher. The notes were compared with the transcribed data and with the second author to check for consistency and/or contradictions.

\subsection{Data Analysis}

Ongoing open coding strategy of grounded theory (Strauss \& Corbin, 1998) was used to identify and analyze the themes within individual and across the four students' stories. The researchers looked for the themes among how the students perceive their experiences and also what they believe to be the factors that enhance and/or limit their learning experiences. This enabled the researchers to look for patterns among the factors contributing to ELLs' academic challenges. Then, the same process was used to identify and analyze the themes within individual and across the five teachers' stories. The researchers then looked for commonalities and gaps among the perspectives of the participating teachers and students.

As in all analyses, the researchers brought particular perspectives and views to the process, which shaped what was seen (and not seen) in terms of data categories. Moreover, because the stories the ELL students and their teachers shared during the interviews pertain to their own perspectives their responses and themes that emerged cannot be generalized. However, the findings from this study do illuminate the importance of attending to the ELL students' beliefs and perspectives about their learning and academic challenges and compare those to their teachers', in order to increase ELLs' voice and thus to provide more equitable educational opportunities for ELLs.

\section{Results}

What surfaced most clearly as a consistent pattern in the data analysis was that both students and teachers in this study predominantly discussed their perspectives on the factors that limit the ELL students' learning. What also surfaced was that there was a clear mismatch between the participating students' and teachers' perspectives on what limits ELLs' learning experiences. Therefore, this study focuses on those findings. Within the students' stories about the factors that limit their learning experiences were three themes and there were two broad themes that surface among the teachers' stories about the factors that limit ELLs' learning experiences.

\subsection{Students}

Below are the students' perspectives on what they see as limiting their learning experiences in school and ESL classes. They are organized in three broad themes.

\subsubsection{Theme one: Boring ESL Class}


Carla told her story about her learning experience in her ESL class in the following way:

ESL class is boring because we don't do anything. I don't really like the teacher because even when we are doing nothing, she doesn't let us talk. And when we do something, sometimes it's same thing over and over.

When the researcher asked Carla to describe the kind of activities they do in the ESL class, she stated,

The teacher sometimes makes us write down different words, like ten times each. It is so boring and I know everyone hates it.

David shared his related story on the subject, saying,

ESL class is where I can fall asleep and not get into trouble. Sometimes the teacher gets mad at me but he doesn't say anything, just looks at me. I don't really care and the teacher does nothing.

Carlos stated,

I think my ESL teacher thinks [that] I know nothing. She tries to teach me stuff I learned a long time ago in Mexico. I am not stupid, you know.

One of the most common misconceptions about linguistically diverse populations is that English language proficiency is linked to intelligence (Cummins, 2000). Indeed, the stories shared by Carla, David, and Carlos show that they are not being challenged cognitively and academically by their ESL teachers. Moreover, according to Cummins' (1979) interdependence hypothesis, the knowledge ELLs have in their first language transfers to their second language. However, the three ELLs stories above illuminate that their ESL teachers do not always provide pedagogical contexts in which ELLs are encouraged to make active transfer between what they know in the first language to the second language. Furthermore, in his Input Hypothesis, Krashen (1982/2009) argued that ELLs should be provided with language instruction that is one step beyond their current language ability. Unfortunately, the ELLs' stories presented here show no sign of them being challenged to learn more advanced materials.

\subsubsection{Theme Two: Teachers Are Mean}

Carlos indicated that most of his teachers were not very nice which does not help him in his school learning experience

Most of my teachers aren't really nice. They don't give me enough time to read and write down things and when I tell them that I need more time, they don't even listen. Some of my teachers are mean, and they don't explain things. When I tell them that I didn't understand, they tell me to pay attention. It's not that I don't pay attention. I just don't understand sometimes because of my English. Last week, in one of my classes, I told the teacher I didn't understand and she told me to ask a friend. What kind of a teacher is she?

Juan told a similar story:

I don't think my teachers like me. They are mean and stuff. When I ask them questions, they say nothing. They just look at me like I am stupid. Understanding directions is hard for me since my English is not that good, and I like teachers who tell me directions to me over and over again until I get it. But sometimes I don't even want to try when my teachers look at me like I am dumb and I just want to give up.

The stories told by Carlos and Juan reveal their frustration with their teachers, as the teachers do not seem to understand the ELLs' academic needs. Research studies show that ELLs need extra time and repetition to process and learn academic content (Peregoy \& Boyle, 2008). However, both Carlos and Juan noted that their teachers do not provide enough time for them to process the course materials and do not repeat parts of the instruction when asked to do so. They both experienced and described the teachers' treatment as mean and not very nice, and they felt misunderstood and disrespected by their teachers. In their view, the teachers see them as lazy, while they tried really hard and all they needed is more time and repetition of instructions. Carlos indicated that he felt misunderstood by his teacher, who believed that he was not paying attention. This was far from reality, as his limited usage of English was causing the difficulty in learning. According to the premise of the Activity Theory which guides this study, learners are active participants of activity (i.e., learning English) and this suggests, the learners, Juan and Carlos, are using their stories to reflect upon their classroom learning experience and their relationship to their teachers in which they do not feel that their teachers respect them. In this regard, some researchers report that when students' do not feel valued by their teachers, students feel powerless and demotivated which in turn delimit their academic and personal growth (Mitra, 2004).

Relatedly, Juan also believed that his teacher viewed him as stupid and dumb, thereby failing to recognize that his limited English was the reason behind needing repeated instructions. Carlos thus questions the teacher's 
credibility, as he does not think that he should have to ask his friend for help during class. In Juan's case, he expressed his feelings of discouragement and desire to give up learning because his teachers are making him feel stupid and dumb.

When the first author asked them if they had teachers they thought were nice, Juan expressed:

I like teachers that take extra time to explain vocabulary and explain again when I don't understand them. Like in my language arts class, the stuff we learn like plant adaptation is hard but I like it because the teacher explains words to me over and over again and I get it.

Carlos similarly expressed:

I had a few teachers who are really nice who don't get mad when I tell them I don't get things and they explain again.

As can be deduced from the stories told by Carlos and Juan, both appreciated the teachers that were willing to take the time to explain the course materials without judging them. Thinking in this way, Strucker et al (2001) propose:

Reach me with more than words from textbooks - but words from the soul and the mind connected to the heart. What got you to teach me? Wasn't it to reach me? ... Relate to me, debate with me, respect me. Stop neglecting me (p. 162).

Similarly, Cruddas and Haddock (2003) found that when students' views were not respected by teachers and that if that lack of respect did not change, then schooling experiences for students could not improve.

\subsubsection{Theme Three: Telling Our Stories}

Carla expressed that her teachers do not let her talk and she does not think learning is fun when she cannot talk. She stated that "I know that my English is not great, but I still like to talk.

I wish my teachers would let me talk to my friends and do group work but it's like they don't want to hear me talk.

When the first author asked Carla to elaborate on her comment, Carla went on to say,

I think, because of my English, my teachers would rather have me stay quiet and say nothing. When I don't say anything in class, I don't feel like I am learning anything.

David told his story in this way:

I wish we get to talk about and write stories of our own life so that we can talk about our life with other people. I think school is more fun in that way. Right now, we mostly write and talk about things that I am not that interested in. In my English class now, the teacher is making us read Shakespeare. I wish I can write about my life in Mexico instead because when they read and talk about Shakespeare, I don't understand. I want teachers to teach better.

According to Krashen (1982/2009), language acquisition and learning requires meaningful interaction in the target language in which ELLs are provided with learning opportunities where they connect with their life experience. Perhaps the required curriculum necessitates teaching Shakespeare. However, to facilitate a learning environment in which ELLs may feel more engaged and valued, it might be necessary for the teacher to make an effort to differentiate her or his instruction in a way that reaches out to their linguistic needs. Moreover, involving students' personal stories and background would not only help them connect their learning to their background experiences but also help them feel a sense of belonging to the classroom community (Echeverria, Vogt, \& Short, 2008). The stories Carla and David shared reflect their view that their learning is sometimes disconnected from their lives. In their view, having more opportunities to talk and share their life stories would benefit their learning.

Moreover, Norton (2000) makes the case that language, identity and language learning commitment is implicated in the investments that teachers have in the practices of classrooms. This concept can be applied to this study to conclude that the ELL students' language learning and their commitment in learning can be partially affected by their teachers' investment in willingness to listen to their students. As Cruddas \& Haddock (2003) warn us, the dominant culture of schooling often prevents teachers from listening to students' creative ideas, and yet, if teachers carefully listen to their students, they can gain deeper insights into students' learning. The ELL participants' small stories in this study reflect the following:

Sometimes I wish I could sit down with one of my teachers and just tell them what I exactly think about their class. It might be good, it might be bad, it's just that you don't have the opportunity to do it (Shultz \& 
Cook-Sather, 2001, p. xii).

\subsection{Teachers}

Below are the teachers' perspectives on what they believe as limiting factors for ELLs' learning experiences. What is notable is that the teachers' perspectives below do not resemble at all the students' perspectives described above. The teachers' perspectives are organized in two broad themes below.

\subsubsection{The Problem with Using Students' First Language}

All five participating teachers concurred that one of the main factors that limit ELLs' learning is the use of students' first language at school and home. These teachers believe that the frequent use of the first language delays the learning of English, the fluency in which they view as essential for ELLs to succeed in their education and lives. Linda commented:

I think that the biggest problem for ELLs is their parents letting them speak Spanish at home all the time. The kids need to speak English and I focus on grammar with my ELLs because that's what they need. I know it is the easy thing to do, and the nice thing to go "Oh, it's okay at home." But, how is talking to the kids in Spanish helping them? Unless your kids are having a meltdown, their parents need to at least try to speak English to them. I think that is the biggest obstacle because, without having these kids learn English, they cannot learn in school.

This teacher locates the biggest problem in ELLs' parents and their continual usage of Spanish in their homes. She does not seem to take into a consideration the possibility that ELLs' parents may not speak English, and more significantly, fails to recognize the value of maintaining ELLs' first language in their learning (e.g., Cummins, 2000). Moreover, this teacher indicates that grammar - the subject she teaches - is influenced by her beliefs. Mary similarly noted:

The parents, teachers, and ELLs must realize the importance of being competent in English and not use so much Spanish. Otherwise, the students will be missing out on all sorts of opportunities. When you go to university, they are not going to translate for you. It's not like "Oh, I am sorry you don't speak English, and here is a Spanish version of biology. We will cater for all your needs." That's just not going to happen. If you work at McDonalds, the customers are not going to speak Spanish to you. You know, if I was French, I am not going to order the La Big Mac. I am going to order the Big Mac and if you don't know what that is, that's tough. Thinking that you can speak your home language in a different country is what's stunting their growth all around.

For this teacher, there is no room for a multilingual society in which many different languages are valued and respected. Karen also stated:

I respect my students' home language, and I think it is great that their parents speak Spanish to them at home. I am all about that. However, I believe that the students who are not proficient in English should not be speaking Spanish at school. The reason is not because I don't respect students' home language but I think using Spanish delays the learning of English, and students are even more confused in learning a new language. To help my students, I usually throw a pizza party for them on Fridays if they spoke no Spanish during class on a given week.

David likewise noted:

In my teaching, I do not usually make reference to the home language of the ELL students I have in class, and I also do not allow my students to speak in their home language in class. I offer practical advice to the ELL students who wish to maintain their home language, but allowing students to speak in their home language at school does not help the students learn English.

While the last two high school teachers quoted above showed their understanding of the importance of and respect for students' home language, they both believe that the use of students' home language interferes with the learning of a second language. Their statements also show that their beliefs directly influence their classroom management strategies, determining what they do or do not do in class. Karen rewards students for not speaking Spanish in class by throwing a pizza party. However, not having a pizza party could equally be viewed as punishment for speaking Spanish in class. The teachers' beliefs discussed so far show that the use of students' home language is viewed as a hindrance to students' learning in general and to their learning English in particular. This view is contradicted by empirical evidence indicating that allowing ELLs to think and use their first language produces a positive, rather than negative, effect on individual learning (De Angelis \& Dewaele, 2009).

In summary, these teachers perceive ELLs' competency in English as the major limiting factor in their academic 
achievement. More specifically, English has been and continues to be a lingua franca in the world, and these teachers' belief that the competency in English is the key factor in becoming successful in school and society is similar to the findings reported by Rhedding-Jones (2002). In this respect, there is no empirical evidence indicating that requiring students to use only English while banning students' first language is beneficial in any way for ELLs' social, emotional, and educational growth.

\subsubsection{Value of Education for Parents}

Three teachers also believed that ELL parents' inability to see the value in their children's education is a limiting factor for ELLs' academic achievement. Linda commented:

I ask myself, "Do the parents value education or not?" I think in the back of their minds, they are thinking that they are eventually going back to their country and so they think "why waste our time?" When parents do not value education, how can you expect their children to value education?

Nancy also noted:

ELL students are very bright and their parents are also very intelligent. I mean, what the parents do is a sign of intelligence - just to pick up their things and move to another country for a betterment of their lives. I don't think I can just do that. The problem is the parents don't believe in themselves and in their children that they can be successful.

David noted likewise:

Students can't learn when they are not in class, and many ELLs often miss class. I don't think parents see how crucial coming to school is. They just let their children stay home. Without parents' support and beliefs that education is important, their children cannot succeed in school.

Here, once again, the teachers perceive individual parents' and students' attitudes towards education as the key factors limiting ELLs' learning. These teachers' beliefs about ELL parents' inability to recognize the value of education are a mere assumption based on their speculation. None of them stated that ELL parents actually told the teachers that they do not value education. These teachers accept the conditions of school as natural, and thus, they are not problematizing the structures of school as a possible challenge for ELLs; rather, they are locating the problems on ELL parents.

\section{Discussion and Implications}

The inability of most US schools to meet the academic needs of ELLs is a national concern (Smith, Coggins, \& Cardosi, 2008), and more equitable educational opportunities for ELLs are indeed a requisite. According to the existing research findings, student voice can serve as a catalyst for change in schools and teacher-student relationships, which leads to positive changes in teaching, curriculum, and assessment (Cook-Sather, 2009; Mitra, 2004; Rudduck \& flutter, 2004). For example, Ogbu (1992) underscored that school success depends not only on what schools and teachers do, but also on what students do.

In the second language education field, increasing students' voice is considered to be an important tool for researchers and teachers to understanding the learning experiences of ELLs (Mitra, 2004, 2008). The data in this study demonstrated that students' perspectives on what they perceive as the limiting factors for their learning are sharply different from those of their teachers. This study also aimed to highlight the importance of perspectives that ELLs bring to school. Students' perspectives in this study showed that their perspectives on, and attitudes toward, their learning are very much influenced by what teachers do and do not do.

On the other hand, the teachers in this study demonstrated their insistence on their students using only English in class and assuming that their belief benefits ELLs which is not surprising, given that an English-only policy has historically dominated the educational policy in the United States (Crawford, 1992). However, the approach in which English-only is imposed, according to empirical evidence, contributes negatively to ELLs' academic, social, and emotional development, even when these teachers have opposite intentions. Though not explicitly visible in this study, the teachers' judgments against ELLs' English proficiency levels and the legitimization of their beliefs will almost certainly impact their teaching, which is a dimension of hegemony and reinforcement of privilege that gets reproduced in local contexts regardless of an individual teacher's recognition. Without an awareness and recognition that ELLs' perspectives can contribute the more productive and equitable learning environment, teachers' may unintentionally but dangerously perpetuate the coercive power relations in which the dominant ideologies of language and learning that are often plainly wrong (e.g., using student's home language is counter-productive to their learning and ELL parents' are not invested in their children's education). 
Oldfather (1995) argues that "learning from student voices...requires major shifts on the part of teachers, students, and researchers in relationships and in ways of thinking and feeling about the issues of knowledge, language, power, and self' $(1995$, p. 87). Much of the literature on good teaching states that teachers must be learners, and we contend that the learning for teachers should extend beyond knowledge in content areas to paying closer attention to students' views and perspectives. We contend that educators must pay attention to the ELLs' perspectives like the ones in this study, as they are instructive and even theoretically sound.

All four ELL students in this study used the opportunity to assert what they see as challenges in their learning, which indicates that they take their learning seriously and want to learn. All four ELL students alluded how their learning is impacted by how teachers perceive them and how they are positioned by teachers as powerless with not much control. While the students' views of their teachers may not appear favorable, presenting them in this study are meant to provide a new way of thinking about teachers' ways of interpreting ELLs' own accounts for their learning.

The researchers of this study recognize that the major problems facing multicultural and multilingual education are historical, social, and systemic and that problems of inequality are usually not caused by something one teacher did. However, we are inevitably constructed within and complicit with the very structures of power within which inequality exists and sometimes flourishes. Thus, if change is to occur, it will be largely a function of how we individuals act (or do not act) in relation to each other. What this means for this study is that how teachers interact with ELLs and the degree to which teachers value ELLs' perspectives not only matters but it is necessary for promoting academic, social and personal success of ELLs. This is instrumental in not only empowering ELLs at the micro classroom level, but also at the macro-level educational structure. Teachers working with ELLs must entertain the possibility of repositioning ELL students as valuable knowledge holders in our classrooms. In closing, to genuinely engage and respect our ELL students' voices also seem to mean teachers respect and empower students' entire beings. Juan stated in his interview: I like school when I feel smart and when my teachers care about me and listen to me. Attending to and increasing ELLs' voices in classrooms means creating more democratic educational contexts for ELLs where they like school and feel smart.

\section{References}

Bamberg, M. (2004). Talk, small stories, and adolescent identities. Human Development, 47, 366-369. https://doi.org/10.1159/000081039

Barkhuizen, G. (1998). Discovering learners' perceptions of ESL classroom teaching/learning activities in a South African context. TESOL Quarterly, 32(1), 85-108. https://doi.org/10.2307/3587903

Basturkmen, H., \& Lewis, M. (2003). Learner perspectives of success in an EAP writing course. Assessing Writing, 8(2002), 31-46.

Bergh, L., Denessen, E., Hornstra, L., Voeten, M., \& Holland, R. W. (2010). The implicit prejudiced attitudes of teachers: Relations to teacher expectations and the ethnic achievement gap. American Educational Research Journal, 47(2), 497-527. https://doi.org/10.3102/0002831209353594

Best, K., Jones-Katz, L., Smolarek, B., Stolzenburg, \& Williamson, D. (2015). Listening to our students: An exploratory practice study of ESL writing students' views of feedback. Tesol Journal, 6(2), 332-356. https://doi.org/10.1002/tesj.152

Cruddas, L., \& Haddock, L. (2003). Girls'voices: Supporting girls' learning and emotional development. Stratfordhire, England: Trentham Books.

Cook-Sather, A. (2009). Learning from the student's perspective: A sourcebook for effective teaching. Boulder, CO: Paradigm Publisher.

Crawford, J. (1992). Hold your tongue: Bilingualism and the politics of "English Only." New York, NY: Addison-Wesley Publishing Company.

Cummins, J. (1979). Linguistic interdependence and the educational development of bilingual children. Review of Educational Research, 49(2), 222-251. https://doi.org/10.3102/00346543049002222

Cummins, J. (2000). Language, power and pedagogy: Bilingual children in the crossfire. Clevedon, UK: Multilingual Matters.

Davis, B., \& Sumara, D. (2002). Constructivist discourses and the field of education: Problems and possibilities. Educational Theory, 52(4), 409-428. https://doi.org/10.1111/j.1741-5446.2002.00409.x

De Angelis, G., \& Dewaele, J. M. (2009). The development of psycholinguistic research on crosslinguistic 
influence. In L. Aronin, \& B. Hufeisen (Eds.), The exploration of multilingualism (pp. 63-77). Amsterdam, Netherlands: John Benjamins. https://doi.org/10.1075/aals.6.04ch4

Dewey, J. (1916). Democracy and education. New York, NY: The Free Press.

Donato, R., \&McCormick, D. (1994). A sociocultural perspective on language learning strategies: The role of mediation. Modern Language Journal, 78, 453-464. https://doi.org/10.1111/j.1540-4781.1994.tb02063.x

Engestrom, Y. (1987). Learning by expanding: an activity theoretical approach to developmental research. Helsinki: Orienta-Konsultit Oy.

Engestrom, Y. (1995). Voice as communicative action. Mind, Culture, and Activity, 2, 192-215. https://doi.org/10.1080/10749039509524699

Echevarria, J., Vogt, M., \& Short, D. (2008). Making content comprehensible for English language learners: The SIOP model. Boston, MA: Pearson/Allyn \& Bacon.

Gal'perin, P. Y. (1969). O metode poetapnogo formirovaniya deystviy [On the method of step-by-step formation of acts]. Voprosi Psychologii, 1, 15-25.

Gay, G. (2010). Acting on beliefs in teacher education for cultural diversity. Journal of Teacher Education, 61(1-2), 143-152. https://doi.org/10.1177/0022487109347320

Good, T. L., \& Brophy, J. E. (1994). Looking in Classrooms. New York, NY: HarperCollins College Publishers.

Ignatyeva, V. L. (2012). Uchebnaya deyatelnost's tochki zreniya teorii deyatelnosti [Learning activity from the perspective of activity theory]. Vestnik MGLU, 16 (649), 63-71.

Kirschner, P. A., Sweller, J., \& Clark, R. E. (2006). Why minimal during instruction does not work: An analysis of the failure of constructivist, discovery, problem-based, experiential, and inquiry-based learning. Educational Psychologist, 41(2), 75-86. https://doi.org/10.1207/s15326985ep4102_1

Krashen, S. D. (1982/2009). Principles and practice in second language acquisition. Oxford, UK: Pergamon

Leont'ev, A. N. (1975). Deyatelnost'. Soznaniye. Lichnost'. [Activity. Consciousness. Personality]. Moscow: Politizdat.

Leont'ev, A. N. (1981). Problems of the Development of Mind. Moscow: Progress.

Levin, B. (2000). Putting students at the center in education reform. Journal of Educational Change, 1, 155-172. https://doi.org/10.1023/A:1010024225888

Milner, H. R. (2003). Teacher reflection and race in cultural contexts: History, meaning, and methods in teaching. Theory into Practice, 42(3), 173-180. https://doi.org/10.1207/s15430421tip4203_2

Mitra, D. L. (2004). The Significance of Students: Can Increasing 'Student Voice' in Schools Lead to Gains in Youth Development? Teachers College Record, 106(4), 651-688. https://doi.org/10.1111/j.1467-9620.2004.00354.x

Mitra, D. L. (2008). Student Voice in School Reform: Building Youth-adult Partnerships that Strengthen Schools and Empower Youth. Albany, NY: SUNY Press.

National Clearinghouse for English Language Acquisition and Language Instruction Educational Programs. (2007). Retrieved from www.ncela. gwu.edu/expert/fastfaq/4.html

$\begin{array}{lllll}\text { National Center for } & \text { Education } & \text { Statistics. } & \text { (2011). Retrieved }\end{array}$ http://nces.ed.gov/nationsreportcard/pdf/studies/2011462.pdf

Norton, B. (2000). Identity and language learning: Gender, ethnicity and educational change. Harlow, UK: Longman/Pearson Education Limited.

Ogbu, J. U. (1992). Understanding cultural diversity and learning. Educational Researcher, 21(8), 5-14. https://doi.org/10.3102/0013189X021008005

Oldfather, P. (1995). Introduction to "learning from student voices. Theory into Practice, 43, 84-87.

Papastergiadis, N. (2000). The turbulence of migration. Malden, MA: Blackwell.

Peregoy, S., \& Boyle, F. (2008). Reading, writing and learning in ESL: A resource book for $k$-12 teachers (5th ed.). Boston, MA: Allyn \& Bacon.

Pettie, S. K. (2011). Teachers' beliefs about English language learners in the mainstream classroom: A review of the literature. International Multilingual Research Journal, 5, 123-147. 
https://doi.org/10.1080/19313152.2011.594357

Pines, C. L. (1993). Ideology and false consciousness: Marx and his historical progenitors. Albany, NY: State University of New York Press.

Rhedding-Jones, J. (2002). English elsewhere: Glocalization, assessment and ethics. Journal of Curriculum Studies, 34(4), 383-404. https://doi.org/10.1080/00220270110108231

Roebuck, R. (2000). Subjects speak out: Howlearners position themselves in a psycholinguistic task. In: J. Lantolf (Ed.), Sociocultural theory and second language learning (pp. 79-96). Oxford: Oxford University Press.

Rubtsov, V. V. (1996). Osnovi socialno-geneticheskoy psikhologii [The foundations of the socio-genetic psychology]. Voronezh, Russia: Institut Prakticheskoy Psikhologii.

Rudduck, J. (2007). Student voice, student engagement, and school reform. In D. Thiessen, \& A. Cook-Sather (Eds.), International Handbook of Student Experience in Elementary and Secondary School (pp. 587-610). Dordrecht, Netherlands: Springer. https://doi.org/10.1007/1-4020-3367-2_23

Rudduck, J., \& Flutter, J. (2004). How to improve your school: Giving pupils a voice. London, UK: Continuum.

Sheng, Z., Sheng, S., \& Anderson, C. J. (2011). Dropping out of school among ELL students: Implications to schools and teacher education. The Clearing House, 84(98), 98-103. https://doi.org/10.1080/00098655.2010.538755

Shultz, J., \& Cook-Sather, A. (Eds). (2001). In our own words: Students' perspectives on school. Lanham. MD: Rowman \& Littlefield.

Smith, J. M., Coggins, C., \& Cardosi, J. M. (2008). Best practices for English language learners in Massachusetts: Five years after the Question 2 mandate. Equity \& Excellence in Education, 41(3), 293-310.

Strauss, A., \& Corbin, J. (1998). Basics of qualitative research: Techniques and procedures for developing grounded theory. Thousand Oaks, CA: Sage.

van Lier, L. (2000). From input to affordance: Social-interactive learning from an ecological perspective. In J. Lantolf (Ed.), Sociocultural theory and second language learning (pp. 245-260). Oxford: Oxford University Press.

Vygotsky, L. S. (1978). Mind in society. Cambridge, MA: Harvard University Press.

Winke, P. (2011). Evaluating the validity of a high-stakes ESL test: Why teachers' perceptions matter. TESOL Quarterly, 45(4), 628-660. https://doi.org/10.5054/tq.2011.268063

Zumwalt, K., \& Craig, E. (2005). Teachers' characteristics: Research on the demographic profile. In M. Cochran-Smith, \& K. M. Zeichner (Eds.), Studying teacher education: The report of the AERA penal on research and teacher education (pp. 111-156). Mahwah, NJ: Lawrence Erlbaum.

\section{Copyrights}

Copyright for this article is retained by the author(s), with first publication rights granted to the journal.

This is an open-access article distributed under the terms and conditions of the Creative Commons Attribution license (http://creativecommons.org/licenses/by/4.0/). 